\title{
Cancer stem cells from human glioma cell line are resistant to Fas-induced apoptosis
}

\author{
JULIAN BERTRAND ${ }^{1}$, GAËLLE BEGAUD-GRIMAUD ${ }^{2}$, BARBARA BESSETTE ${ }^{1}$, \\ MIREILLE VERDIER $^{1}$, SERGE BATTU ${ }^{2}$ and MARIE-ODILE JAUBERTEAU ${ }^{1}$ \\ ${ }^{1}$ Laboratory of Immunology, Faculty of Medicine, and ${ }^{2}$ Laboratory of Analytical Chemistry, Faculty of Pharmacy, \\ Equipe Accueil 3842 (IFR 145) University of Limoges, 2 rue Docteur Marcland, 87025 Limoges cedex, France
}

Received September 5, 2008; Accepted November 10, 2008

DOI: 10.3892/ijo_00000198

\begin{abstract}
Glioblastoma is the most common primary brain tumor, characterized by its resistance to treatments. To define efficient therapy, the origin of tumor-forming cells needs to be elucidated in order to search for new therapeutic pathways. The objective of this study was to determine the different cell populations constituting a human glioblastoma cell line, U-87 MG and their sensitivity to apoptosis induced through the activation of Fas, a membranous death receptor. By a cell sorting method, the sedimentation field flow fractionation, two major cell subpopulations were identified, a most differentiated cell fraction, containing large and adherent cells, sensitive to Fas-induced apoptosis and another one, characterized by small cells forming aggregates, expressing CD133, a marker of stem cells and more resistant to Fas-activated apoptosis. By using a selective method of culture, adapted for neural stem cell cultures, we have verified that the U-87 MG cell line contained cancer stem cells similar to the immature ones obtained by the cell sorting method. Interestingly, while these tumor stem cells, expressing CD133, were resistant to Fas-induced apoptosis, monomeric form of Fas protein was detected predominantly in these cells. In contrast, the most mature cells, responsive to Fas-activated apoptosis, collected in another cell fraction, contained oligomeric aggregates of Fas protein, a pre-signalling form of the Fas receptor, essential for the initiation of apoptosis through its activation. These results suggest that these immature stem cells in glioma could be an important factor of resistance to chemotherapy requiring apoptosis through Fas signalling system. Indeed, future strategies of treatment, inducing differentiation of these stem cells need to be considered to enhance therapeutic efficiency.
\end{abstract}

Correspondence to: Dr M.O. Jauberteau, Laboratory of Immunology, Faculty of Medicine, University of Limoges, 2 rue du Docteur Marcland, 87025 Limoges, France

E-mail: m-o.jauberteau-marchan@unilim.fr

Key words: apoptosis, cancer stem cells, glioblastoma, Fas, cell sorting, sedimentation field flow fractionation

\section{Introduction}

Glioblastoma multiform is the most common malignant primary brain tumor in adults and it is among the most lethal of all cancers (1). Gliomas are particularly invasive tumors and their prognosis remain very poor despite surgeryradio- and chemotherapy (2), with a mean survival $<1$ year. Glioma cells are characterized by their resistance to induce apoptosis and by some features of immature cells. The neural stem-cell model for the origins of gliomas shed light on their heterogeneity (3). Recently, self-renewing, multipotent cells expressing the CD133 surface cell-marker were isolated from human gliomas and transplanted into adult mouse brain, where they recapitulated the parents tumor's histology (4). These findings suggest that gliomas are both initiated and maintained by a small fraction of cancerous neural stem-cells. Therefore, $\mathrm{CD}_{133}{ }^{+}$cells are obviously considered as a potentially relevant target tumor cell subpopulation for therapy in the context of the whole tumor mass (4).

Apoptosis plays an important role in regulation of cellular activities in eukaryotes (5), and its deregulation contributes to the pathogenesis of several diseases (6). The Fas receptor (APO-1, CD95) is a member of the tumor necrosis factor (TNF)/nerve growth factor death receptor superfamily and its monomeric form is a $45-52-\mathrm{kDa}$ type I transmembrane protein (7). Fas extracellular domain contains three cystein-rich repeats and two of them bind the Fas natural ligand, FasL (8). Their disruption leads to the loss of ligand binding and effector's signalling (9). It was first demonstrated that following engagement with FasL or agonistic anti-Fas monoclonal antibody (mAb), Fas monomers trimerize, which leads to the recruitment of the intracellular death domain and to a downstream activation of the death-inducing signalling complex (10). Subsequently, the adaptor protein Fas-associated death domain interacts with Fas cytoplasmic death domain and recruits procaspase- 8 , which can thereby self-activate. Cleavage of downstream substrates by caspase- 8 rapidly triggers cell death (11). More recently, Fas trimerization was shown to occur also without FasL binding. This preassembly of Fas monomers, named the pre-ligand assembly domain is required for the subsequent clustering of Fas receptor after FasL ligation (12). Fas polymerization leads to sodium dodecyl sulfate (SDS) - stable high molecular weight aggregates that are easily detected by SDS-polyacrylamide gel electrophoresis 
(SDS-PAGE) (13). Indeed, apoptosis induced through Fas pathway is depending on the pre-association of Fas receptor onto the cell membrane. This pre-association is potentially regulated by phosphorylation of extra cellular part of receptor, leading to the inhibition of Fas pre-association (14). However, it is worth noting that other non-apoptotic functions were associated to Fas/FasL interaction such as neuritogenesis of dorsal root ganglia (15) or survival and growth of some tumor cell lines (16). Hence, the resistance of tumor cells to Fas-mediated apoptosis needs to be evaluated in the choice of cytotoxic drugs that kill drug-sensitive cells by inducing the Fas system (17). It has been reported that some glioma cells express both Fas (18) and FasL (19) but although expressing substantial levels of Fas, these cells are generally resistant to cell death induced by FasL treatment (18).

To define the degree of resistance to Fas-activated apoptosis in glioblastoma and its relationship to the immature stage of these cells, this report focused on the isolation of immature and tumor neural stem-cells contained in a human glioma cell line, U-87 MG and their responsiveness to Fasinduced apoptosis. Two methods were used to obtain immature and tumor cell stems, a cell-sorting method, the sedimentation field flow fractionation (SdFFF) able to separate immature and differentiated cells as previously demonstrated (20-22) and a longest selection method based on the growth properties of tumor stem cells in a defined culture medium (23).

This study showed that Fas activation by an agonistic monoclonal antibody (mAb) induced apoptosis of the most differentiated cells. Consequently, by using the properties of SdFFF, we demonstrated that the functional effects of Fas activation in U-87 MG cells depended on the differentiation stage of these cells. Indeed, the subpopulation of tumor neural stem-cells, expressing CD133 marker which was isolated from this cell line by SdFFF or obtained by selective culture medium, exhibited a significant resistance to Fasinduced apoptosis, compared to the most differentiated cells isolated in another SdFFF fraction. These finding were assessed also on tumor stem cells cultured in defined medium. Interestingly, these immature tumor cells were resistant to Fas-induced apoptosis. Therefore, this subpopulation of tumor cells could be implicated in the resistance of glioblastoma to conventional treatments, potentially unable to induce apoptosis of these immature cells, explaining the relapse occurring after treatment. Indeed, it seems of major interest to identify immature and cancer stem cells in order to evaluate their sensitivity to new molecules in therapeutic research pathways.

\section{Materials and methods}

Cell line and cell culture. The U-87 MG human glioblastoma cell line was obtained from American Type Culture Collection (ATCC, LGC Promochem SARL, Molsheim, France). The cells were maintained in MEM with Earle's salts (Gibco BRL, Life Technologies, Paisley, UK) supplemented with $10 \%$ decomplemented foetal calf serum (FCS), $1.5 \mathrm{~g} / 1$ sodium bicarbonate, $1 \%$ non-essential amino acids, sodium pyruvate $(2 \mathrm{mM})$, penicillin $(50 \mathrm{U} / \mathrm{ml})$, streptomycin $(50 \mathrm{U} / \mathrm{ml})$, L-glutamine $(2 \mathrm{mM})$ and fungizone $(0.1 \%)$ (Gibco BRL). Cells were grown in $25 \mathrm{~cm}^{2}$ flask (Nunc Fisher Bioblock
Scientific, Illkrich, France) at $37^{\circ} \mathrm{C}$ in a humidified $5 \% \mathrm{CO}_{2}^{-}$ 95\% air incubator.

Freshly versenized, $10^{6}$ cells were seeded onto flasks $\left(25 \mathrm{~cm}^{2}\right)$ for 3 days before SdFFF analysis. Cell viability was determined by trypan-blue exclusion: cell concentration was adjusted to $2.5 \times 10^{6}$ cells $/ \mathrm{ml}$ in phosphate buffered saline (PBS) before SdFFF analysis. After SdFFF sorting, control and eluted cells were seeded $\left(10^{5}\right.$ cells/well) in 24-well-plates (Nunc, Fisher Bioblock Scientific). For light microscopy, cultured cells were examined under phase-contrast microscopy (magnification $\mathrm{x} 400$ ). Photos were taken with a Nikon camera (Champigny/Marne, France).

To obtain neurosphere-like cells, U-87 MG cells were cultured in serum-free medium (23) containing DMEM/F12, $30 \%$ glucose (Sigma Aldrich, Saint-Quentin-Fallavier, France), 1 M HEPES buffer (Sigma), progesterone (Sigma), putrescine (Sigma), B27 growth supplement (Invitrogen), $20 \mathrm{ng} / \mathrm{ml} \mathrm{EGF}$ (Sigma), 20 ng/ml FGF (Sigma), Insulin-Transferrin-Sodium Selenite Supplement (Roche Diagnostics, Meylan, France) and heparin (Sigma). After a 4-day culture, U-87 MG formed primary neurospheres. Primary neurospheres were dissociated and cells were seeded to form secondary neurospheres, cultured during $48 \mathrm{~h}$ before immunostaining and apoptosis studies.

Immunocytofluorescence staining. For immunofluorescence studies, cells were grown on glass coverslips in a 24-well plate. After two washes in PBS, the cells were fixed for $15 \mathrm{~min}$ in $4 \%$ paraformaldehyde in PBS, washed twice in PBS and permeabilized 30 min with a solution of Triton X-100 0.1\%-PBS at room temperature. Then, cells were washed twice in PBS and incubated in PBS-4\% bovine serum albumin (BSA) for $2 \mathrm{~h}$ at room temperature. Cells were incubated overnight at $4^{\circ} \mathrm{C}$ with primary antibodies (Abs) diluted in PBS-BSA. The following antibodies were used: a mouse anti-vimentin monoclonal Ab (mAb) (clone RV202, 1:200 dilution, Santa Cruz Biotechnology, Heidelberg, Germany), a rabbit polyclonal anti-CD133 (clone RB 1784, 1:100 dilution, Abgent, San Diego, CA), or anti-glial fibrillary protein (GFAP) (1:500 dilution, DakoCytomation, Trappes, France). Negative controls were done with cells incubated with irrelevant normal rabbit or mouse IgG (Santa Cruz).

Cells were washed twice in PBS and incubated with $1 \mu \mathrm{g} / \mathrm{ml}$ Alexafluor 488- or 596- conjugated anti-mouse or anti-rabbit immunoglobulin (Ig) Abs (Invitrogen) for $120 \mathrm{~min}$ at $4^{\circ} \mathrm{C}$. After two further washes in PBS, cells were mounted in glycerol-gelatin medium (Sigma-Aldrich) and fluorescence was analyzed using a Leica DMRX microscope (Leica Microsystems, Rueil-Malmaison, France).

Flow cytometry analysis. Cells were harvested, washed with PBS, fixed and permeabilized with IntraStain (DakoCytomation), before staining with the Abs recognizing vimentin, CD133 or GFAP purchased as above. Fas expression was analyzed with a rabbit anti-Fas polyclonal $\mathrm{Ab}$ (clone C-20, Santa Cruz) specific of the intracellular part of the receptor, at a dilution of $1: 100$ in $\mathrm{PBS}$ for $30 \mathrm{~min}$ at $4^{\circ} \mathrm{C}$, and revealed by Fluorescein isothiocyanate (FITC)-conjugated anti-rabbit Ig (Santa Cruz) at a dilution of 1:200 in PBS for $30 \mathrm{~min}$ at $4^{\circ} \mathrm{C}$ before analysis by flow cytometry (Beckman FC 500, Beckman Coulter Villepinte, France). Moreover 
phycoerythrin (PE)-conjugated anti-Fas mAb (clone IM1739, Beckman Coulter) and PE-conjugated anti-neural cell adhesion molecule (N-CAM) mAb (clone NKH1 RD1, Beckman Coulter) were used at a dilution of 1:100 in PBS for $30 \mathrm{~min}$ at $4^{\circ} \mathrm{C}$. Cells stained with either rabbit or mouse isotypic irrelevant Ig (Santa Cruz) were used as controls to determine background and positivity thresholds. Ten thousand cells were acquired; data were analyzed using the computer program WinMDI (version 2.8).

Apoptosis quantification. After a 48-h culture, cells were treated with $40 \mathrm{ng} / \mathrm{ml}$ of anti-Fas agonistic mAb (Fas clone 7C11 sodium azide-free, Beckman Coulter) (24). After a 24-h treatment, apoptosis was analyzed by two methods. One method, measuring cytoplasmic soluble mono- and oligo-nucleosomes released during apoptosis, was based on enzyme-linked immunosorbent assay (ELISA) using antibodies directed against DNA and histones (Cell Death Detection ELISA ${ }^{\text {PLUS }}$, Roche Diagnostics, Meylan, France) according to the manufacturer's protocol to quantify apoptotic index as previously described (25).

Another method used Annexin-V-FITC staining (Beckman Coulter) which indicates phosphatidylserin translocation to the cell surface in apoptotic cells. This staining was associated to those of propidium iodide (PI, red fluorescence), a DNAintercalating agent that reflected the membranous permeability as observed during necrosis or at the latter stage of apoptosis. Cells were analyzed by flow cytometry (Beckman FC 500).

SdFFF device and cell elution conditions. SdFFF separation device used in this study derived from those previously described and schematized $(26,27)$. The apparatus consists of two $938 \times 40 \times 2 \mathrm{~mm}$ polystyrene plates, separated by a mylar ${ }^{\circledR}$ spacer in which the channel was curved. Channel dimensions were $818 \times 12 \times 0.175 \mathrm{~mm}$ with two $50 \mathrm{~mm} \mathrm{~V}$-shaped ends. The measured total void volume (channel volume + connecting tubing + injection and detection device) was $1792 \pm 2.00 \mu 1$. Void volume was calculated after injection and elution time determination of a non-retained compound $(0.10 \mathrm{~g} / \mathrm{l}$ of benzoic acid, UV detection at $254 \mathrm{~nm}, \mathrm{n}=6)$. The channel rotor axis distance was measured at $\mathrm{r}=14.82 \mathrm{~cm}$. A Waters 590 programmable HPLC pump (Waters Associates, Milford, MA) was used to pump the sterile mobile phase. The elution signal was recorded at $254 \mathrm{~nm}$ by means of a M1111 (100 mV input) acquisition device (Keithley, Metrabyte, Tauton, MA) operated at $4 \mathrm{~Hz}$ and connected to a Macintosh computer. The optimal elution conditions were determined experimentally and were: flow injection through the accumulation wall of $100 \mu 1$ of $\mathrm{U}-87 \mathrm{MG}$ cell suspension $\left(2.5 \times 10^{6}\right.$ cells $\left./ \mathrm{ml}\right)$; flow rate: $0.80 \mathrm{ml} / \mathrm{min}$; mobile phase: sterile PBS, pH 7.4 (Gibco BRL); external multi-gravitational field strength: $24.50 \pm 0.05 \mathrm{~g}$ and spectrophotometer detection at $\lambda=254 \mathrm{~nm}$ (Waters 486 Tunable Absorbance Detector, Waters Associates).

For this device, sedimentation fields were expressed in units of gravity, $1 \mathrm{~g}=980 \mathrm{~cm} / \mathrm{s}^{2}$, and calculated as previously described (27). A M71B4 Carpanelli engine associated with a pilot unit Mininvert 370 (Richard Systems, Les Ullis, France), controlled the rotating speed of the centrifuge basket. Sample injections were done by means of a Rheodyne ${ }^{\circledR}$
7125 i chromatographic injector (Rheodyne, Cotati, CA, USA). Cleaning and decontamination procedures have been described in a previous report (28).

For this population, fractions were collected and designated as follow: TP, the total peak; and PF, peak fractions. For cell sorting, 4 fractions were collected: TP ( 2 min $20 \mathrm{sec}$ to $8 \mathrm{~min}$ $00 \mathrm{sec}$ ) and $-\mathrm{PF} 1(2 \mathrm{~min} 20 \mathrm{sec}$ to $4 \mathrm{~min} 15 \mathrm{sec}), \mathrm{PF} 2(4 \mathrm{~min}$ $20 \mathrm{sec}$ to $6 \mathrm{~min} 00 \mathrm{sec}$ ) and PF3 (6 min $10 \mathrm{sec}$ to $8 \mathrm{~min} 00 \mathrm{sec}$ ). To obtain a sufficient quantity of cells for cultures, and further analyses successive SdFFF cumulative fraction collections were performed (10 to 15 ).

Coulter counter. A 256 channels Multisizer II Coulter Counter (Beckman Coulter) was used to determine the mean cell population diameter. Crude population or SdFFF collected fractions were diluted in Isoton ${ }^{\circledR}$ to a final volume of $15 \mathrm{ml}$. The counting conditions were $500 \mu 1$ sample volume, cumulating three successive assays. Results are displayed as the mean \pm SEM for three different experiments.

Western blotting. After SdFFF analysis cells were lysed in RIPA lysis buffer (50 mM HEPES, pH 7.5, $150 \mathrm{mM} \mathrm{NaCl}$, $1 \%$ deoxycholate, $1 \%$ Nonidet P-40, $0.1 \%$ SDS, and $20 \mu \mathrm{g} / \mathrm{ml}$ aprotinin) containing protease inhibitors (Complete Mini; Roche Diagnostics).

Equal amounts of proteins from cell lysates (40 $\mu \mathrm{g} /$ lane) were separated on NuPAGE 4-12\% SDS-polyacrylamide gels (Invitrogen) under denaturing conditions and transferred onto nitrocellulose sheets (Hybond, GE Heathcare, Orsay, France). Non-specific binding sites were blocked for $2 \mathrm{~h}$ with $5 \%$ non-fat dry milk in TBS containing $0.1 \%$ Tween- 20 . After overnight incubation at $4{ }^{\circ} \mathrm{C}$ with anti-Fas rabbit polyclonal Ab (clone C20, Santa Cruz,) and anti-Fas mAb (clone B10, Santa Cruz) (1/200 dilution) (both directed against intracellular part of the receptor), membranes were incubated with horseradish peroxidase (HRP)-conjugated Abs to mouse or rabbit Ig (1/2000 dilution, DakoCytomation) for $60 \mathrm{~min}$ at room temperature and revealed by chemiluminescence (ECL reagent, Amersham Life Science, Inc., Buckinghamshire, UK). Protein loading control was performed with rabbit anti-GAPDH Ab (Santa Cruz Biotech). Western blots were scanned using a bio-imaging system (Genesnap, Syngene, Cambridge, UK).

Statistical analysis. Mean and standard errors (SEM) were evaluated in three independent experiments. Statistical analysis was carried out by ANOVA test using Statview (Ver. 5.0). A $\mathrm{p}<0.05$ (Fisher's PLSD test) was considered as significance.

\section{Results}

Characterization of $U-87$ MG cells. U-87 MG cell line is a heterogeneous model which contains two cell-types: adherent cells and small sphere cells forming aggregates (Fig. 1A).

To characterize the U-87 MG cell line we used Abs recognizing three different markers: GFAP (an astrocytic cell marker), vimentin (a weakly differentiated cells marker) (29) and CD133 (a stem cell marker) (30).

The majority of U-87 MG cells were stained with antiGFAP Ab (Fig. 1B); this result was confirmed by flow 


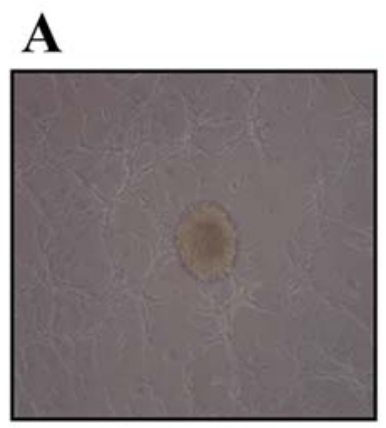

D

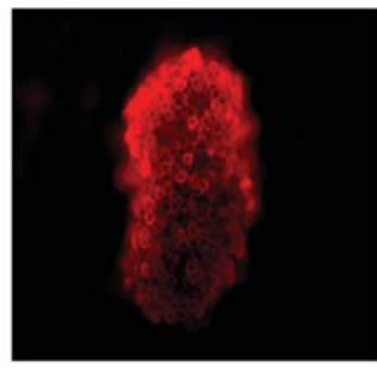

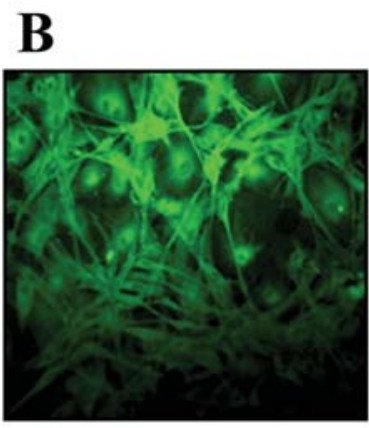

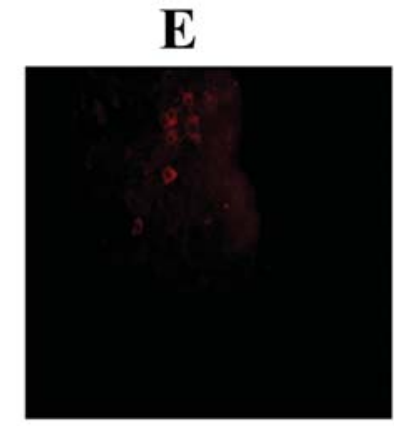

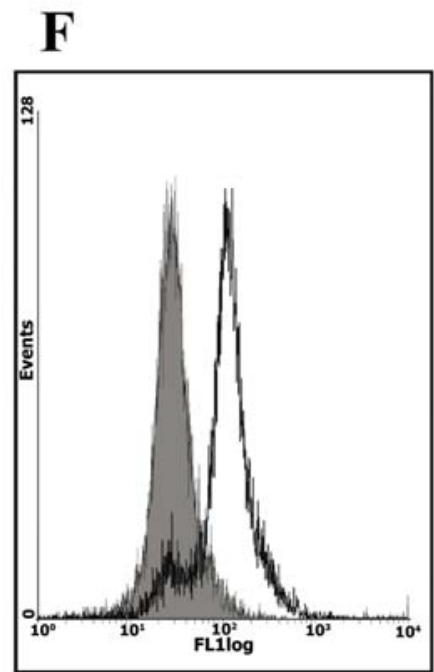
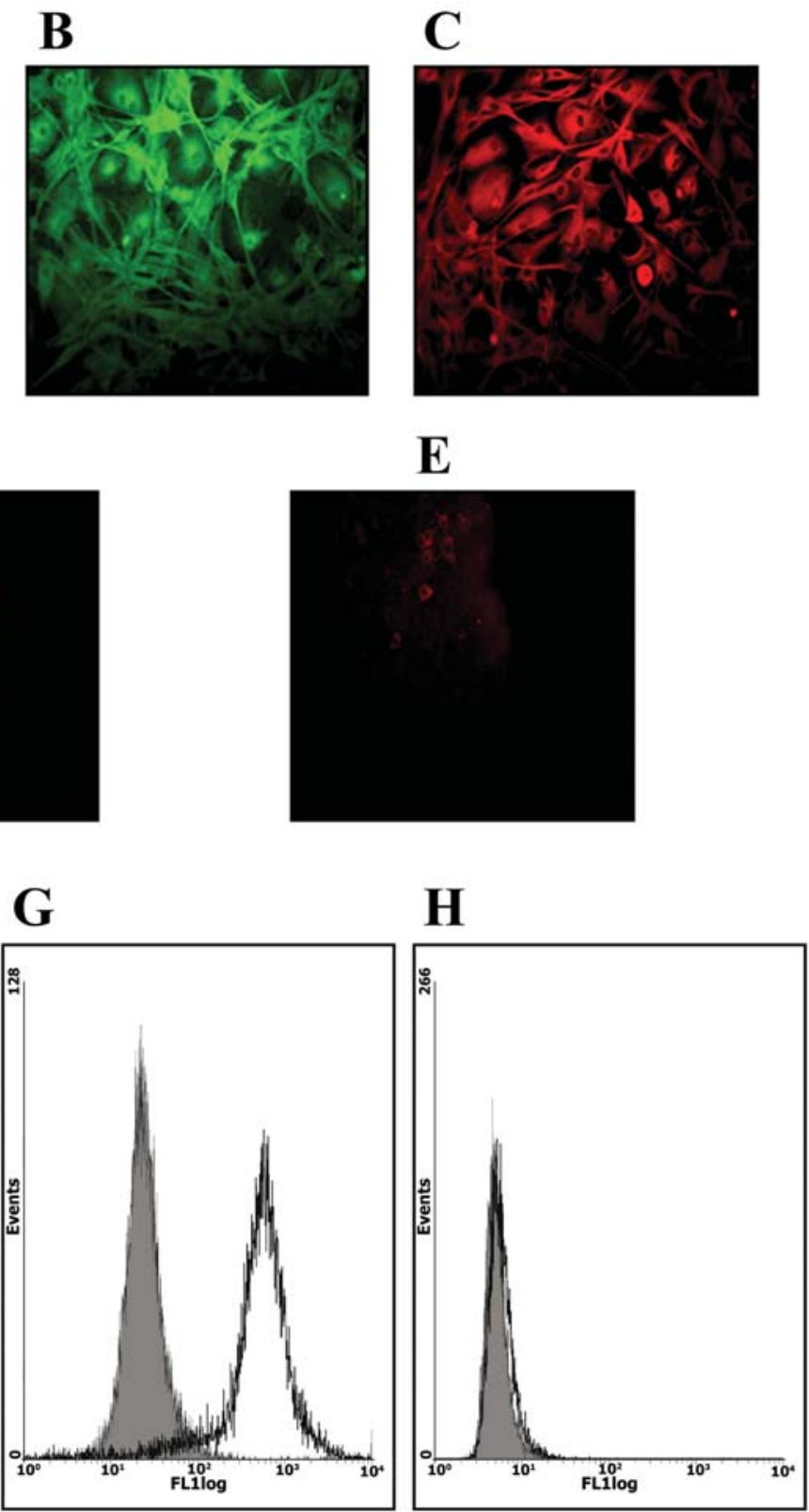

Figure 1. Characterization of U-87MG cell line. Cells in cultures (A) analyzed by microscopy and immunofluorescence with anti-GFAP (B), anti-vimentin (C and D) and anti-CD133 (E) antibodies. Flow cytometry analysis of cells using same antibodies: anti-GFAP (F), anti-vimentin (G) and anti-CD133 (H); a representative result of three independent experiments (isotypic control superimposed in gray). (Magnification: A, x200; B-E, x400).

cytometry (Fig. 1F). The anti-vimentin staining demonstrated that all cells were positive (Fig. 1C and G). Moreover, the strongest intensity of vimentin staining seemed to be in small sphere cells (Fig. 1C) and in cells present in aggregates (Fig. 1D). Finally, by using CD133 marker, we detected some $\mathrm{CD} 133^{+}$cells in aggregates (Fig. 1E), whereas these cells were not detected by flow cytometry in total cell population (Fig. 1H).

Fas-induced apoptosis in total U-87 MG cells. To define the potential apoptotic functions of Fas receptor in glioblastoma, apoptosis induced through the Fas pathway was evaluated in U-87 MG cells, expressing Fas receptor as assessed by flow cytometry analyses, by using antibodies directed either against intracellular or extra-cellular part of Fas receptor (Fig. 2A and B).
After a 48-h culture, Fas activation was performed by a 24-h incubation of cells with an agonistic anti-Fas mAb (7C11 - $40 \mathrm{ng} / \mathrm{ml})$. Apoptosis was significantly induced through Fas activation as detected by two methods. Indeed, the measurement of soluble nucleosomes by ELISA showed an increase of apoptotic ratio of cells incubated with anti-Fas $\mathrm{mAb}$ (Fig. 2C) in comparison to cells cultured in basal conditions ( $\mathrm{p}=0.0059)$. These results were confirmed by flow cytometric analysis showing the percentage of apoptotic cells, only labelled by annexin-V (Fig. 2D represents one of the three independent experiments). However, this method showed that only a small percentage $(18.43 \%)$ of cells of the total population underwent to apoptosis in presence of agonistic anti-Fas $\mathrm{mAb}$, since $9.21 \%$ where stained in basal conditions $(\mathrm{p}=0.008)$. Interestingly, this second method was able to distinct a cell subpopulation sensitive to Fas-induced 
A

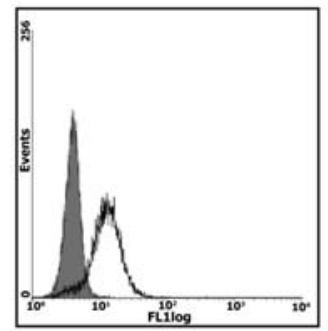

C
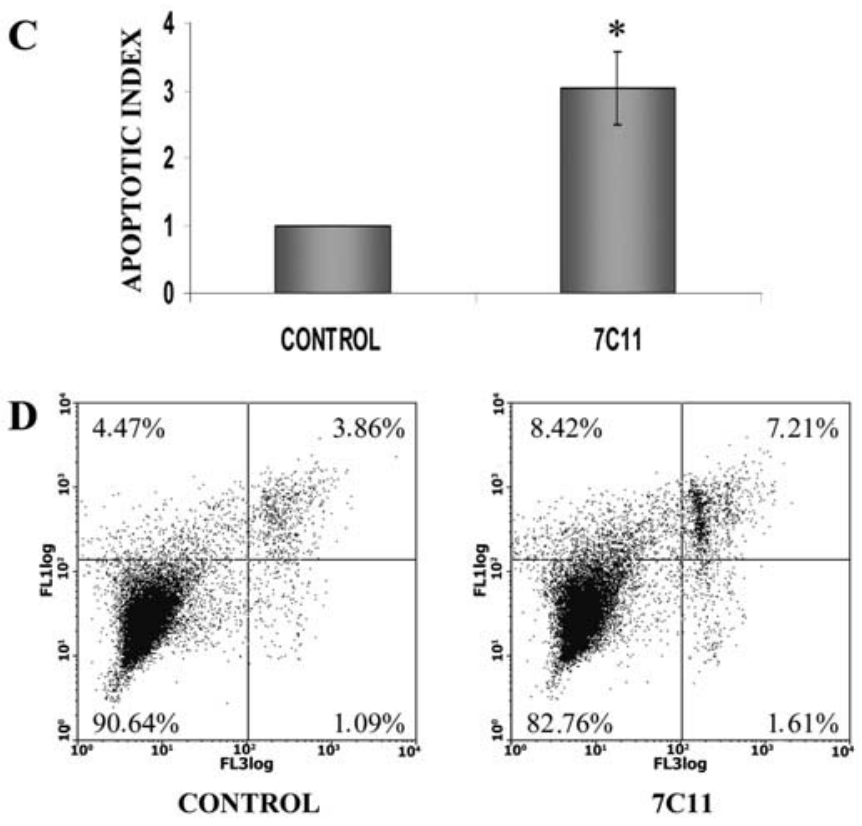

Figure 2. Fas-induced apoptosis in whole U-87MG cell line. Expression of Fas intracellular (A) and extracellular (B) domains, by flow cytometric analysis. Apoptosis induced by a 24-h exposure to anti-Fas agonistic monoclonal antibody (7C11) compared to basal apoptosis (control) evaluated either by ELISA measurement of cytoplasmic release of nucleosomes (apoptotic index) (C) ( ${ }^{*}$ significant p-value) or by flow cytometry of annexin-V staining (D), a representive result of three independent experiments.

apoptosis, among the prominent other one resistant to Fasactivated apoptosis. Therefore, the following results focused: i) on the isolation of these two cell populations and ii) on their apoptotic response through Fas activation pathway.

Distinct cell populations identified by SdFFF elution. To isolate and study these two subpopulations, we used an innovative tool called Sedimentation field flow fractionation (SdFFF). Fig. 3 displayed a representative fractogram of U-87 MG cells. The first part of fractogram corresponded to the void volume peak $\left(\mathrm{R}_{\mathrm{obs}} \approx 1\right.$, retention ratio $\mathrm{R}_{\mathrm{obs}}=$ void time versus retention time $=t_{0} / t_{R}$ ) (31) while the second and broader part, corresponded to the cell elution profile.

Elution conditions have been experimentally determined to allow separation of larger cells from void volume peak, reducing selective cells subpopulation lost. Then, $a R_{\text {obs }}$ value was specifically measured for the more retained cells corresponding to the last fraction and smaller cells (Fig. 3). $\mathrm{R}_{\mathrm{obs}}$ $\mathrm{F} 3=0.351 \pm 0.021(\mathrm{n}>6)$. As previously described $(32,33)$, the absolute $\mathrm{R}_{\mathrm{obs}}$ value particularly depends on culture conditions, thus for U-87 MG cells the number of cell passages which should range from 2 to 8 . At constant flow rate $(0.80 \mathrm{ml} / \mathrm{min})$,

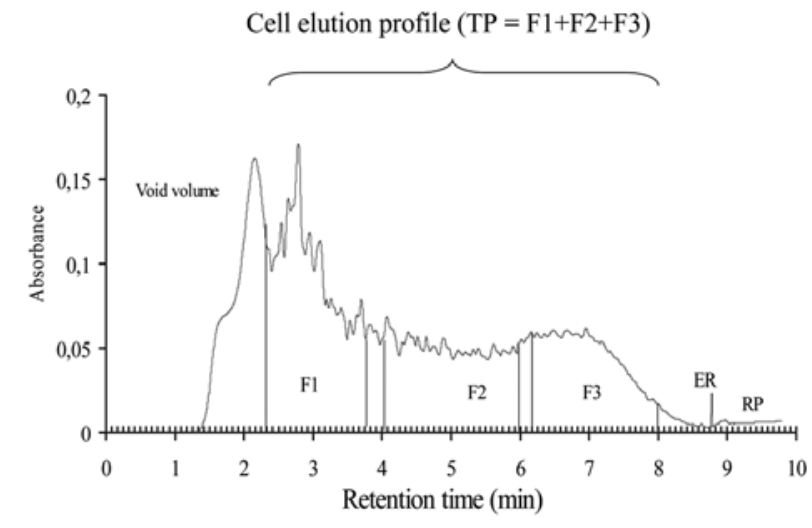

Figure 3. Representative fractogram of U-87 MG cell sorting by Sd FFF. Eluted fractions of U-87 MG cells: TP, total peak; and PF, peak fractions. For cell sorting: 4 fractions of cell sub-populations were collected: TP ( $2 \mathrm{~min}$ $15 \mathrm{sec}$ to $8 \mathrm{~min} 00 \mathrm{sec}$ ) representative of the whole cell population and PF1 ( $2 \mathrm{~min} 15 \mathrm{sec}$ to $3 \mathrm{~min} 50 \mathrm{sec}$ ), PF2 (4 min $00 \mathrm{sec}$ to $6 \mathrm{~min} 00 \mathrm{sec}$ ) and PF3 (6 min $10 \mathrm{sec}$ to $8 \mathrm{~min} 00 \mathrm{sec}$ ). Elution conditions were: flow injection of $100 \mu \mathrm{l}$ of U-87 MG cell suspension $\left(2.5 \times 10^{6}\right.$ cells $\left./ \mathrm{ml}\right)$; flow rate, $0.80 \mathrm{ml} / \mathrm{min}$; mobile phase, sterile PBS, $\mathrm{pH} 7.4$; external multi-gravitational field strength, $24.50 \pm 0.05 \mathrm{~g}$; spectrophotometer detection at $\lambda=254 \mathrm{~nm}$. ER, end of channel rotation. RP, release peak of reversible cell-accumulation wall sticking. Successive SdFFF cumulative fraction collections were performed: 8-10 to obtain a sufficient quantity of cells for next experiments.

according to the 'Hyperlayer' elution mode description (31,33-39), the $R_{\text {obs }}$ value for F3 is field dependant: $R_{\text {obs }}=$ $0.366 \pm 0.012(n=3)$ at $20.00 \mathrm{~g}$. By using the following equation (40):

$$
\mathrm{R}=\frac{6 \mathrm{~s}}{\omega}
$$

in which $\mathrm{R}$ is the retention ratio, $\omega$ is the channel thickness $(175 \mu \mathrm{m})$, and $\mathrm{s}$ the distance from the center of the focused zone to the channel wall (40), we calculated the approximate average cell elevation ( $\mathrm{s}$ ) using $\mathrm{R}_{\mathrm{obs}}$ values: $\mathrm{s}=10.24 \mu \mathrm{m}$. The mean cell diameter for F3 was $12.74 \pm 0.10 \mu \mathrm{m}(\mathrm{n}=3$, Coulter Counter $\left.{ }^{\circledR}\right)$. Thus, radii of last eluted cells were less than the approximate average cell elevation value: $r=6.37$ $<\mathrm{s}=10.24 \mu \mathrm{m}$. Finally, after total cell elution, when the external field was turned off (mean external field $=0.00 \mathrm{~g}$, end of rotating, ER) (Fig. 3), we observed a residual signal (RP, Fig. 3) corresponding to the reversible particle release from the accumulation wall. Four cell fractions were collected: i) the total peak fraction (TP) which corresponded to the total U-87 MG eluted population; and ii) peak fractions 1, 2 and 3 (PFn) which were time-dependent collected fractions of retained cells (Fig. 3).

Morphological observations. After SdFFF elution cells were cultured for $4 \mathrm{~h}$ and observed by optical microscopy. Fig. 4A show that TP contained two cell types: adherent cells and small sphere cells. PF1 was composed by a majority of adherent cells (Fig. 4B), PF2 was a mix between the two cells type (Fig. 4C) whereas small sphere cells were observed in PF3 (Fig. 4D). These different observations demonstrated that SdFFF could separate two cell types: large adherent cells in PF1 and small sphere cells in PF3. Moreover, size and density of the four fractions studied by flow cytometry (Fig. 5) 
A

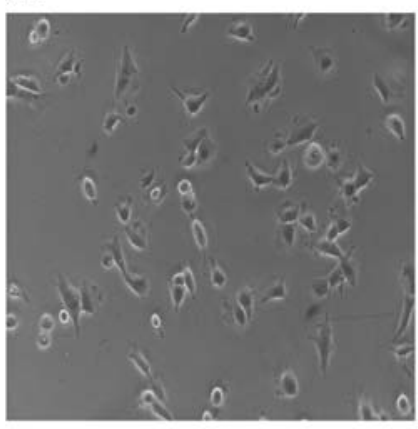

TP
B

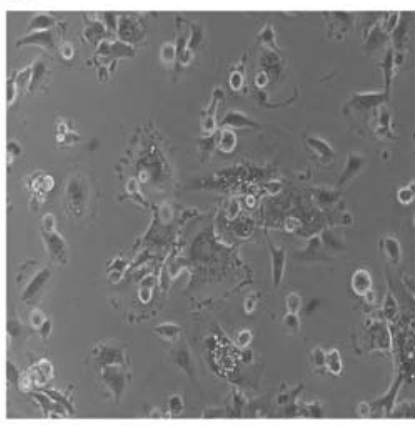

F1

D

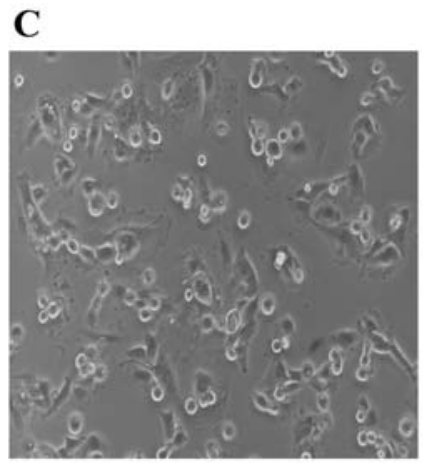

F2

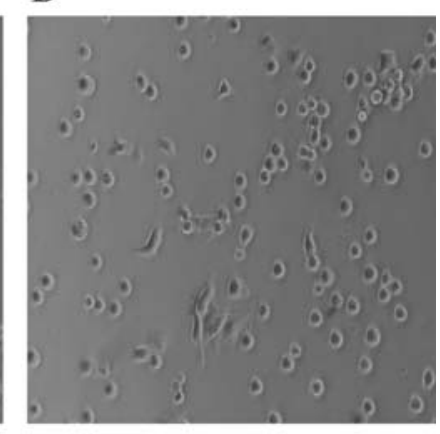

F3
Figure 4. Morphological aspects of cells in culture. After a 4-h subculture, cell fractions were observed by optical microscopy. TP (A) contained two cell types: adherent and small sphere cells. Most of adherent cells were localized in F1 (B) and F2 (C) whereas small sphere cells were observed in F3 (D). Magnification x400.

showed that PF3 was enriched with small cells, confirming optical microscopic observations.

Characterization of SdFFF fractions by flow cytometry. Three markers, N-CAM, vimentin and CD133 have been used for characterization. First, N-CAM was used to characterize the adherent cells in glioma. Global expression of N-CAM, observed in the TP revealed that $56.6 \%$ of cells were $\mathrm{N}^{-C A M}{ }^{+}$ (Fig. 6A). Furthermore, PF1 and PF2, the two enrichedadherent cell fractions, contained 74 and $78.6 \% \mathrm{~N}-\mathrm{CAM}^{+}$ cells, respectively (Fig. 6B and C), whereas in PF3, 59.9\% $\mathrm{N}-C A M^{+}$cells were detected (Fig. 6D).

Then, vimentin, expressed in cells in proliferation and differentiation and generally characteristic of the weakly differentiated cells (29) was assessed. The total expression of vimentin, analyzed in the TP (Fig. 7A) was similar to those in PF1 and PF2 cells (Fig. 7B and C) while vimentin expression was more strongly expressed in PF3 (Fig. 7D). These results demonstrated different vimentin expression levels between the three fractions with highest level in PF3, containing the most immature cells as hypothesized by morphological features.

Indeed, we analyzed this cell fraction with anti-CD133 Ab, CD133 being described as a stem cell marker (30). CD133 staining was reported to be associated to brain stem tumor-initiating cells, that reconstitute the original tumor in vivo and after transplantation (4). By flow cytometry, CD133
A

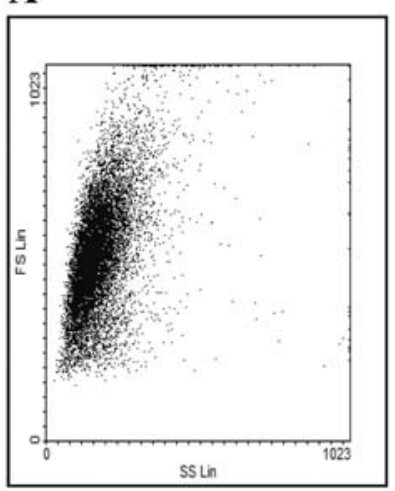

TP

C

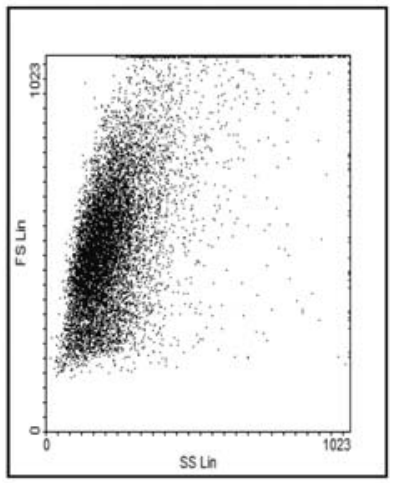

F2
B

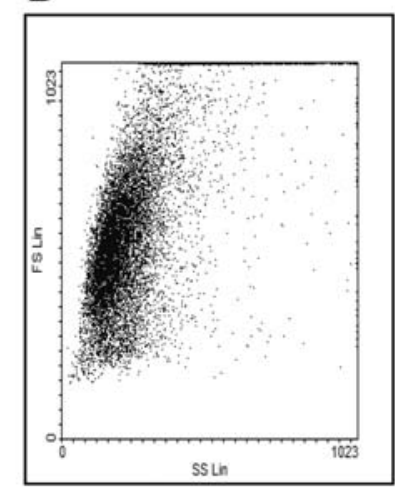

F1

D

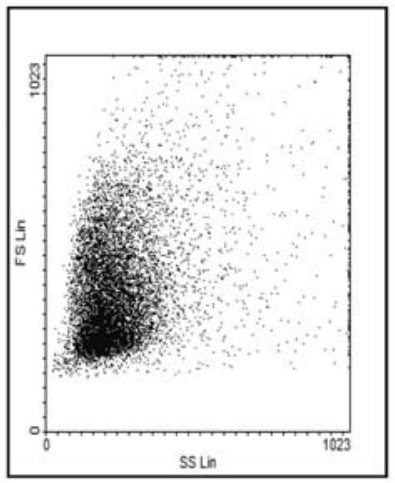

F3

Figure 5. Study of cell size and density after SdFFF elution. The study of cell size and density in fractions TP (A), F1 (B), F2 (C) and F3 (D), by flow cytometry showed that smallest cells were contained in $\mathrm{F} 3$.

expression was detected in a small percentage $(11.8 \%)$ of total cell line and of the TP (Fig. 8A). Interestingly, PF3 was strongly enriched with $72 \% \mathrm{CD} 133^{+}$-expressing cells (Fig. 8D), in contrast to other fractions, $\mathrm{PF} 1$ and PF2, containing 12.95 and $25 \% \mathrm{CD} 133^{+}$cells, respectively (Fig. $8 \mathrm{~B}$ and C). Together, these markers revealed that the F3 cell subpopulation contained cells expressing immature (vimentin ${ }^{+}$) and stem cell markers $\left(\mathrm{CD} 133^{+}\right)$, in contrast to $\mathrm{F} 1$ cell sub-population, containing most mature $\left(\mathrm{N}-\mathrm{CAM}^{+}\right)$cells.

U-87 MG cells cultured in serum-free medium. To obtain CD133+-enriched cells, U-87 MG cells were cultured in FCS-free medium (23). Contrasting with the two different cell types detected in U-87 MG cell line cultured with FCS-containing medium (adherent cells and cells forming aggregates) (Fig. 9A), U-87 MG cells cultured in serum-free medium displayed neurosphere-like aggregates (Fig. 9B and C). Study of cell size determined by flow cytometry showed that cells in FCS-free medium (Fig. 9E) were smaller than cells cultured in normal (FCS-containing) medium (Fig. 9D). In these conditions, the staining of cells with anti-CD133 Ab demonstrated that $34.38 \%$ cells were $\mathrm{CD} 133^{+}$(Fig. 9F and G) a percentage significantly higher than in FCS-containing medium ( $\mathrm{p}=0.0074)$. Therefore, U-87 MG cells cultured in FCS-free medium formed neurospheres containing CD133+ stem cells. 
A

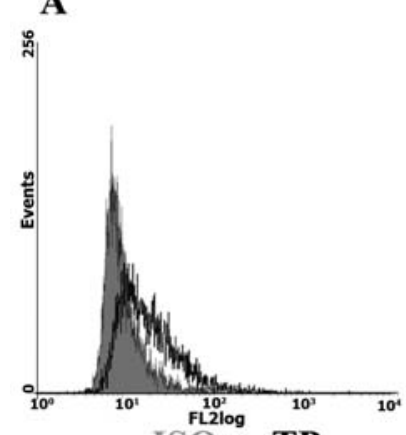

ISO vs TP

C

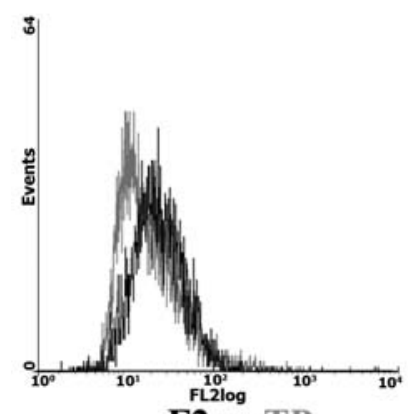

F2 vs TP
B

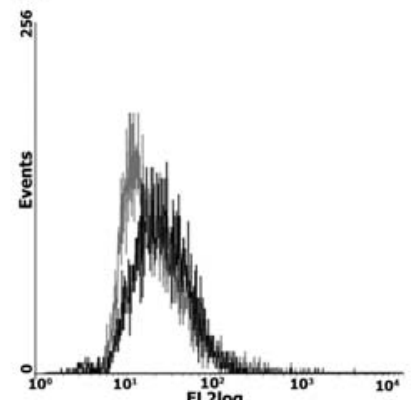

F1 vs TP

D

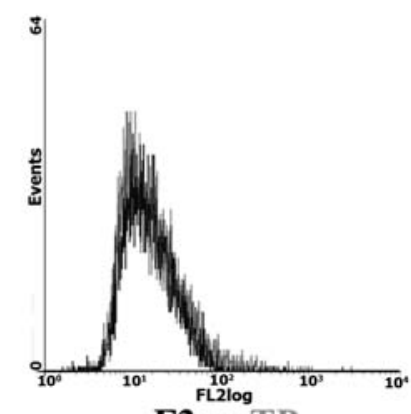

F3 vs TP

Figure 6. N-CAM expression in eluted fractions. N-CAM expression was measured by flow cytometry after SdFFF elution. N-CAM-expressing cells were evaluated in TP (A) in comparison to isotypic control (ISO). N-CAM ${ }^{+}$ cell enrichment was detected in F1 (B) and F2 (C) but not in F3 (D) (compared to $\mathrm{N}-\mathrm{CAM}$ expression in $\mathrm{TP}$, superimposed in grey). A representative experiment of three independent tests.

Oligomeric aggregate Fas receptor detected in the eluted fraction PF1 (most mature cells) but not in PF3 (immature cells). Fas receptor was expressed in the different cell sorting fractions as shown by Western blotting (Fig. 10A). However, some differences of Fas protein oligomerization were identified among the eluted cell fractions. Whereas Fas monomer $(45 \mathrm{kDa})$ was detected in the 3 fractions and in the whole cell population (TP), a higher molecular weight protein of $120 \mathrm{kDa}$ was the predominant form detected in the whole cell and PF1 protein lysates. In contrast, PF3 proteins, containing mostly the monomeric form. This high molecular weight of Fas receptor was detected with an antibody directed against the intracellular part of the receptor, available to detect the aggregated Fas receptor (14), described as the effective form of pre-associated Fas receptor, able to induce apoptosis (10).

Different sensitivity to Fas-induced apoptosis depending on cell maturation. The apoptotic response to a 24-h incubation with agonistic anti-Fas mAb (7C11-40 ng/ml) was different between

Figure 8. CD133 expression in eluted fractions. After the SdFFF elution, flow cytometry analysis of CD133 expression, detected in whole cell population (TP) compared to isotypic control (ISO) (A) was similar to those in F1 (B) and F2 (C) sub-populations (compared to TP staining superimposed in black). In contrast, F3 sub-population is enriched in $\mathrm{CD}_{133^{+}}$ cells (D, compared to TP staining in black). A representative result of three independent experiments.
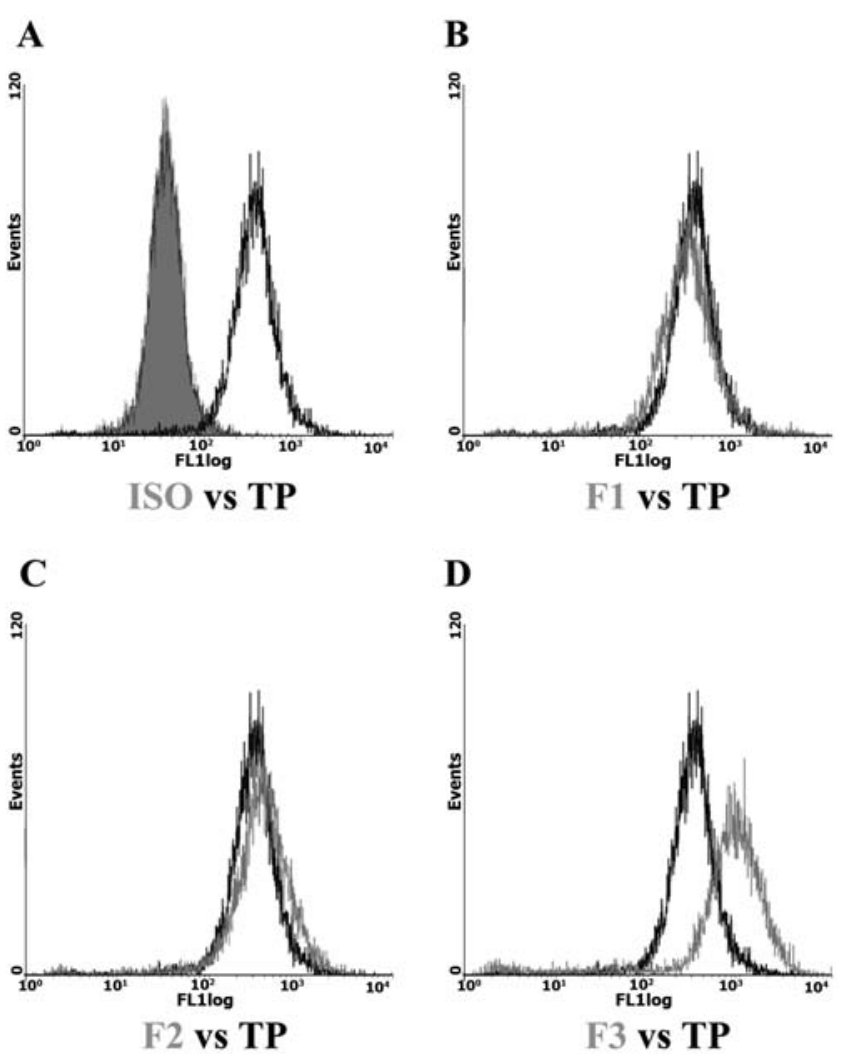

Figure 7. Vimentin expression in eluted fractions. After SdFFF elution, vimentin expression, evaluated by flow cytometry in whole cell population, represented in TP (A, compared to isotypic control in grey) is superimposable to cell expression in F1 and F2, while the highest vimentinexpressing cells were detected in F3 (D). A representative result of three independent experiments, F1, F2 and F3 vimentin expression was compared to those of total cells (TP, superimposed in black).
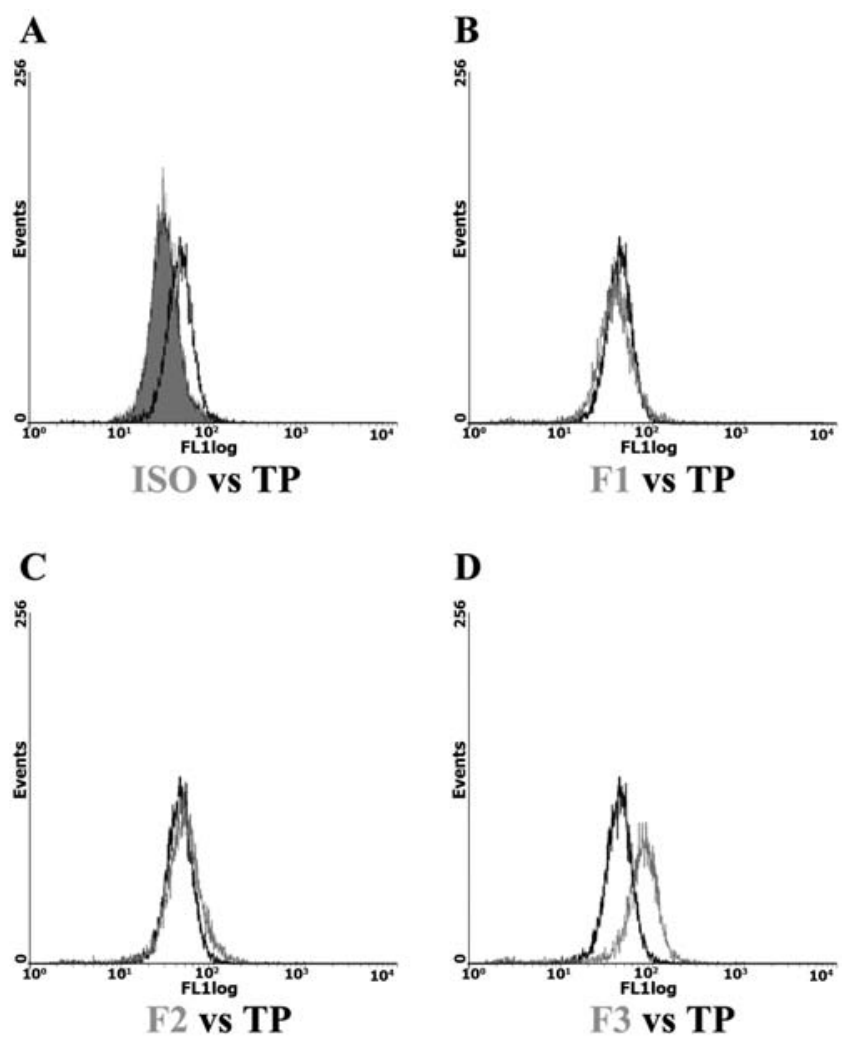

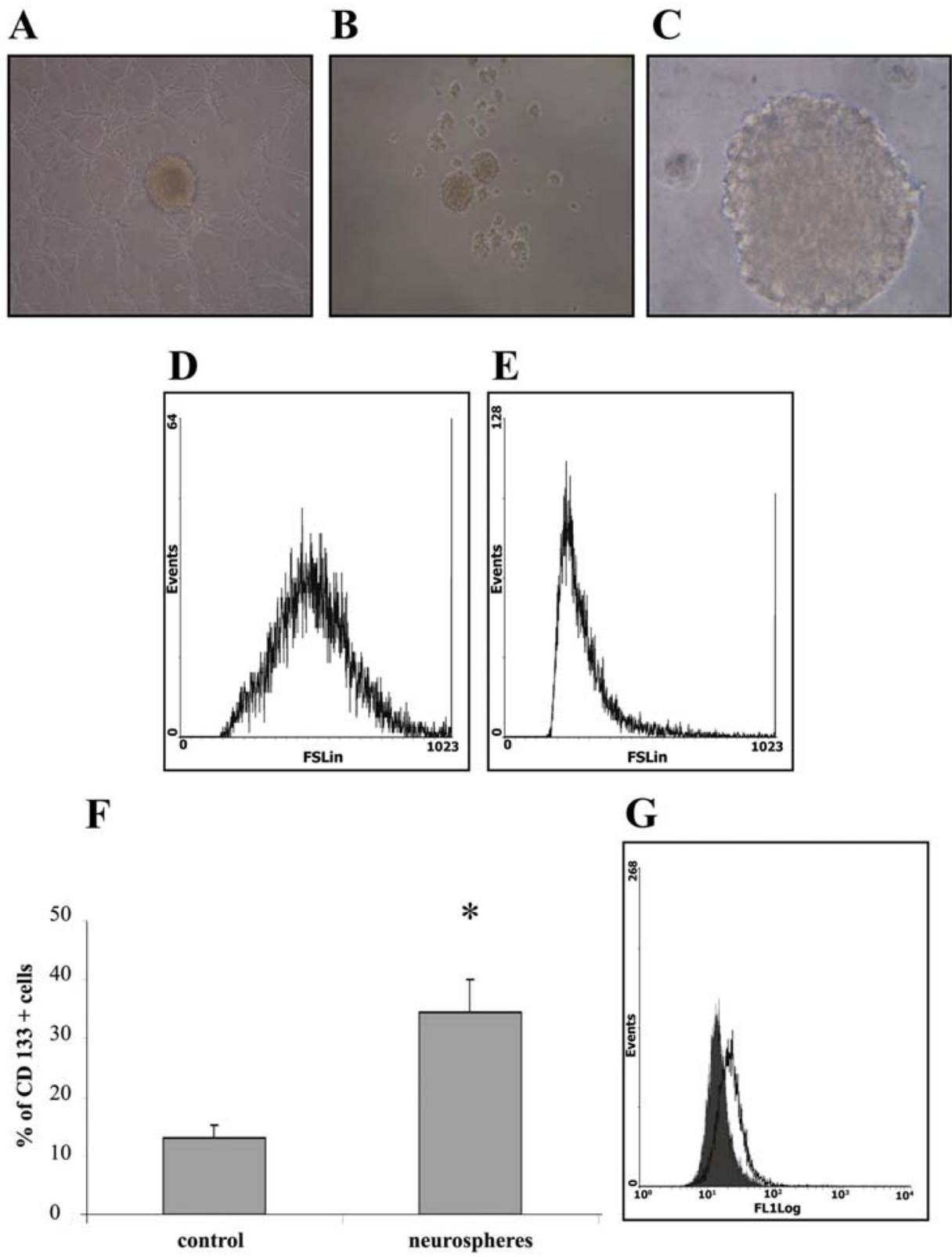

Figure 9. U-87MG cells cultured in serum-free medium. Whereas two different cell types were detected in U-87 MG cell line cultured with FCS-containing medium (adherent cells and cells forming aggregates) (A), cultures in serum-free medium contained cells aggregated in neurospheres (B and C). Cell size determined by flow cytometry showed that cells in free medium (E) were smaller than those cultured in FCS-containing medium (D). The percentage of CD133-expressing cells was significantly higher in cultures maintained in serum-free (neurosphere-like) than cells cultured in FCS-contained medium (F) ("significant p-value, three independent experiments). A representative result of CD133 expression (G) in serum-free cultures, compared to normal FCScontaining medium (superimposed in grey).

the eluted cell fractions as assessed by annexin- $\mathrm{V}$ staining (Fig. 10B). Indeed, a significant difference was detected between the 3 SdFFF fractions: most mature cells (PF1 sub-population) exhibited the highest apoptotic rate $(38 \%)$, whereas, sensitivity to apoptosis of immature cells (PF3 sub-population), was significantly lower $(25 \%)$ ( $\mathrm{p}=0.0314$, Fig. 10B). An intermediate stage of sensitivity to apoptosis $(30 \%)$ was detected in eluted cells from intermediate fraction, PF2, which was similar to those obtained in whole cells, obtained after cell sorting (TP; 32\%). In contrast, basal apoptosis (without Fas activation) of total cells (contained in PT) after cell sorting by SdFFF was lower, 20\% (data not shown).
Likewise, stem cells forming neurosphere-like, obtained in serum-free medium, were insensitive to a 24-h incubation with the agonistic anti-Fas $\mathrm{Ab}(7 \mathrm{C} 11-40 \mathrm{ng} / \mathrm{ml})(17.33 \pm 2.14 \%$ of apoptotic cells). Apoptotic ratios were similar to those obtained in cells cultured in basal conditions $(15.36 \pm 1.42 \%$, $\mathrm{p}>0.05$ ) (Fig. 10C). These results demonstrated that cells present in neurospheres were resistant to Fas-induced apoptosis which assessed results obtained in SdFFF eluted cells.

\section{Discussion}

The aim of this study was to determine the sensitivity difference of human glioma cells to Fas-induced apoptosis 

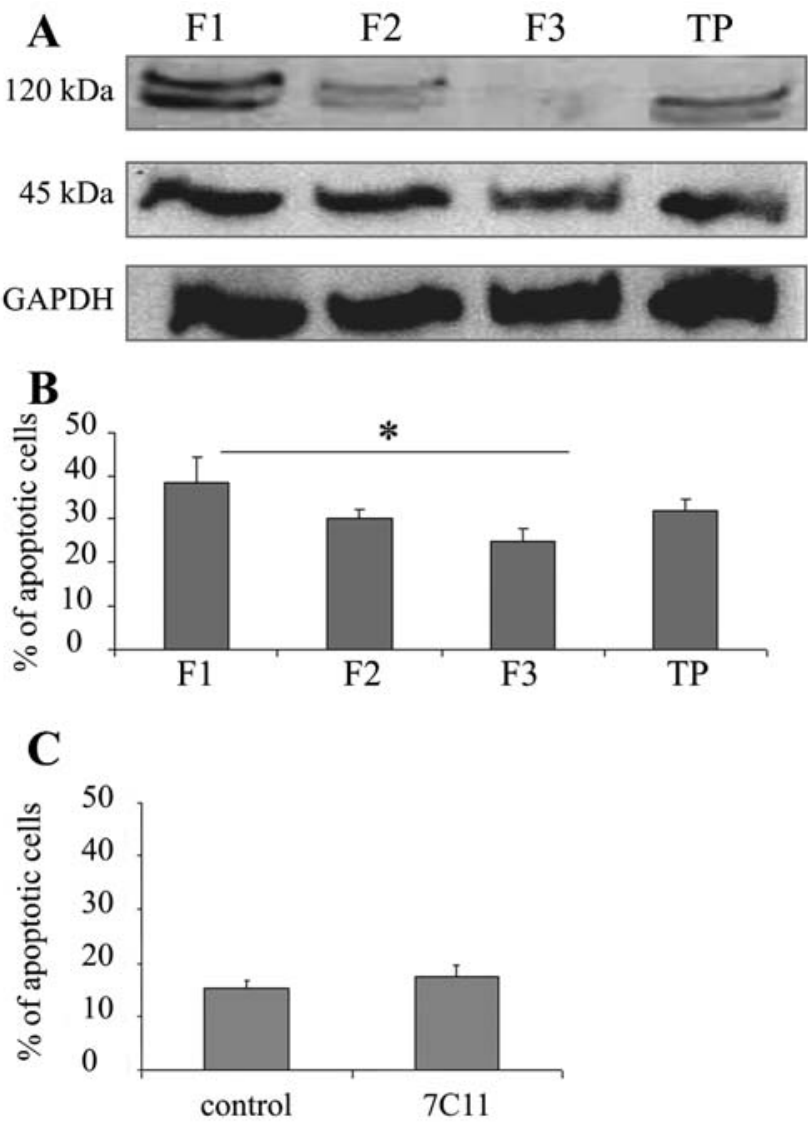

Figure 10. Comparative effect of Fas activation depending on maturation stage of cells in Sd FFF isolated fractions and in glioma neural stem cells Western blotting of U-87 MG cell proteins with anti-Fas mAb directed against intracellular part of Fas receptor (A), detection of monomeric form of Fas $(45 \mathrm{kDa})$ in the three eluted cell fractions (F1, F2, F3) as in the whole population. The oligomeric aggregates of Fas receptor $(120 \mathrm{kDa})$ were not detected in F3. GAPDH, detected by specific $\mathrm{Ab}$, is the control of protein loading. Apoptosis induced by agonistic anti-Fas mAb (7C11) studied by annexin-V staining revealed that apoptosis was significantly $\left(^{*}\right)$ higher in F1 cells than in F3 (B). Cells cultured in serum-free medium were resistant to 7C11-induced apoptosis (C) as assessed by similar apoptotic percentage in cells maintained in serum-free medium without Fas activation (control).

among the maturation stage of cells contained in the human U-87 MG line. Such objective was supported by the hypothesis that resistance of gliomas to treatment could be due to some difference in sensitivity to apoptosis induction among cells contained in the U-87 MG glioma cell line. The induction of apoptosis through the death receptor, Fas, by an agonistic $\mathrm{mAb}(7 \mathrm{C} 11)$ was evaluated in the whole cell population showing that only a small fraction of total population was sensitive to Fas-activated apoptosis. In order to separate sensitive and resistant cells to Fas-induced apoptosis, we have studied the apoptotic response in different fractions obtained after SdFFF U-87 MG cell sorting, a non-invasive and tagless method for cell separation that was previously used in different application fields of oncology $(27,32,33,41-43)$. Different aspects have been evaluated including: i) monitoring of the apoptosis or differentiation induction $(32,33,42,43)$; ii) cell sorting of specific subpopulations [pre-apoptotic (33), differentiated cells (32)]; iii) kinetics of apoptosis (27). SdFFF was also used to sort specific phenotypes from complex cancer cell populations such as neuroblastomas (26), or to sort immature cancer cells (22), two applications which can be directly used in this study.

As previously described $(22,27,33,39,44,45)$, cell species are eluted under the Hyperlayer model, a size/density dependent cell elution mode $(31,33-39)$, which predicts that large and weaker cells are focused in faster streamlines to be eluted first. Hyperlayer elution mode allowed, by limiting cell-accumulation wall interactions, a cell elution which: i) respected repeatability, reproducibility and recovery; ii) respected cell functional integrity; iii) provided high levels of short and long-term viability (no apoptosis induction); iv) respected the maturation and differentiation stages; and finally; v) enhanced better sub-population sorting and characterization $(20,22,26,27)$.

U-87 MG cell line appeared as a heterogeneous population (Fig. 4), leading, as for neuroblastoma cell line (26), to complex fractograms (Fig. 3) in contrast to many other cell lines $(22,27,42,43)$. According to results concerning: i) the particle elution away from the accumulation wall $(\mathrm{s}>\mathrm{r})$; ii) field dependence of the Robs value; and iii) the limited interactions between cells and accumulation wall leading to low reversible cellular release (RP, Fig. 3); we can suppose that U-87 MG cells were eluted under Hyperlayer elution mode as it has been demonstrated for other cell models $(22,26,27,44,45)$.

However, from a biological point of view, we did not know if cell sorting of the different U-87 MG sub-populations of interest was achieved. Four cell fractions were collected: the total peak fraction (TP) which corresponded to the total U-87 MG population eluted, used as control of whole cells; and three peak fractions 1,2 and $3\left(\mathrm{PF}_{\mathrm{n}}\right)$ which are the timedependent collected fractions of the retained peak profile. Cell culture, morphological observation, specific antigen expression and apoptosis analysis were performed in each fraction in order to characterize these different sub-populations and to determine their respective apoptosis sensitivities to Fas activation.

A previous study on the neuroblastoma cell line IMR-32 (26) showed that SdFFF could separate two phenotypes from the same cell lineage: the first N-phenotype forming a pool of quiescent undifferentiated cells and the second able to proliferate and to give rise also adherent S-type cells (26). In this way, we demonstrated that SdFFF could separate two phenotypes from U-87 MG: large adherent cells in PF1 and small sphere cells in PF3. Moreover, the characterization by flow cytometry of these two sub-populations (PF1 and PF3) determined that cells eluted in PF3 were the most undifferentiated, containing the highest vimentin labeling (29). On the other hand, the neural stem cells marker CD133 (30) allowed us to demonstrate the SdFFF capacity to isolate cancer neural stem cells. Likewise, SdFFF analysis could separate two distinct cell phenotypes: i) in PF1: most differentiated large adherent cells, CD133-; and ii) in PF3: most undifferentiated small sphere cells, $\mathrm{CD} 133^{+}$. Therefore, Fas activation was studied on these two phenotypes PF1 and PF3. First, we have shown that no significant difference between basal apoptotic rates of the different fractions (data not shown) was observed. However, we have calculated a higher basal apoptotic rate $(20 \%)$ after SdFFF elution than calculated in U-87 MG cell line, possibly due to the use of high external field for separating larger cells from void 
volume. Nevertheless, the study of Fas-activating apoptosis in SdFFF eluted fractions, showed a significant difference between PF1 and PF3. Indeed, cells sorted in PF1 (large adherent cells, and CD133-) seem to be the most sensitive to the apoptosis induced by Fas receptor activation while cells in PF3 (small sphere cells, most undifferentiated and CD133+) are the most resistant to Fas-induced apoptosis. A previous study demonstrated that $\mathrm{CD} 133^{+}$cells were responsible of preservation and proliferation of the tumor in glioma (3). Therefore, this tumor cell sub-population could be implicated in the resistance of glioblastoma to Fas-induced apoptosis. The culture in defined serum-free medium was described to be a selective growth medium of enriching neural stem cells in cultures from normal brain tissues (46) as brain tumor (23). In comparison, $\mathrm{SdFFF}$ cell sorting also performed the isolation of cancer stem cells, expressing CD133+. Furthermore, cells obtained by this selective culture method exhibited resistance to apoptosis, similar to those sorted in PF3. Therefore, we could assess that SdFFF is able to quickly separate immature cancer stem cells, expressing CD133, from most differentiated (CD133-) and adherent, N-CAM-expressing cells. N-CAM expression in gliomas was described to enhance adhesion and reduce cell invasion and tumor growth (47) and is expressed by normal differentiated astrocytes (48). These adherent cells, eluted in PF1, contained oligomeric aggregates of Fas receptor, the initial signalling form of Fas (10) and were sensitive to apoptosis through Fas pathway. In contrast CD133+ PF3 cells contained mostly the monomeric form of Fas receptor and were resistant to apoptosis induced through Fas activation.

As glioblastomas were described to be due to abnormal differentiation of neural stem cells belonging to the subventricular zone (3), it seems of first importance to focus research on new therapeutic pathways to eradicate cancer stem cells, isolated from tumor patients. The conditions for inducing differentiation of these immature cells need to be further defined in order to re-establish the response of gliomas to chemotherapy.

\section{Acknowledgements}

This work was supported by grants from Conseil Régional du Limousin and Ligue Nationale Contre le Cancer (comité de la Corrèze).

\section{References}

1. Taghian A, Suit H, Pardo F, Gioioso D, Tomkinson K, DuBois W and Gerweck L: In vitro intrinsic radiation sensitivity of glioblastoma multiforme. Int J Radiat Oncol Biol Phys 23 : 55-62, 1992.

2. Leibel SA and Sheline GE: Radiation therapy for neoplasms of the brain. J Neurosurg 66: 1-22, 1987.

3. Sanai N, Alvarez-Buylla A and Berger MS: Neural stem cells and the origin of gliomas. N Engl J Med 353: 811-822, 2005

4. Singh SK, Hawkins C, Clarke ID, Squire JA, Bayani J, Hide T, Henkelman RM, Cusimano MD and Dirks PB: Identification of human brain tumour initiating cells. Nature 432: 396-401, 2004.

5. Stennicke HR, Jürgensmeier JM, Shin H, Deveraux Q, Wolf BB, Yang X, Zhou Q, Ellerby HM, Ellerby LM, Bredesen D, Green DR, Reed JC, Froelich CJ and Salvesen GS: Pro-caspase-3 is a major physiologic target of caspase-8. J Biol Chem 273 27084-27090, 1998.
6. Sharma K, Wang RX, Zhang LY, Yin DL, Luo XY, Solomon JC, Jiang RF, Markos K, Davidson W, Scott DW and Shi YF: Death the Fas way: regulation and pathophysiology of CD95 and its ligand. Pharmacol Ther 88: 333-347, 2000.

7. Baker SJ and Reddy EP: Modulation of life and death by the TNF receptor superfamily. Oncogene 17: 3261-3270, 1998.

8. Nagata S and Golstein P: The Fas death factor. Science 267: 1449-1456, 1995.

9. Chan WH, Yu JS and Yang SD: Apoptotic signalling cascade in photosensitized human epidermal carcinoma A431 cells: involvement of singlet oxygen, c-Jun N-terminal kinase, caspase-3 and p21-activated kinase 2. Biochem J 351: 221-232, 2000.

10. Kischkel FC, Hellbardt S, Behrmann I, Germer M, Pawlita M, Krammer PH and Peter ME: Cytotoxicity-dependent APO-1 (Fas/CD95)-associated proteins form adeath-inducing signaling complex (DISC) with the receptor. EMBO J 14: 5579-5588, 1995.

11. Muzio M, Chinnaiyan AM, Kischkel FC, O'Rourke K, Shevchenko A, Ni J, Scaffidi C, Bretz JD, Zhang M, Gentz R, Mann M, Krammer PH, Peter ME and Dixit VM: FLICE, a novel FADD-homologous ICE/CED-3-like protease, is recruited to the CD95 (Fas/APO-1) death-inducing signaling complex. Cell 85: 817-827, 1996.

12. Chan FK: The pre-ligand binding assembly domain: a potential target of inhibition of tumour necrosis factor receptor function. Ann Rheum Dis 59: 50-53, 2000.

13. Algeciras-Schimnich A, Shen L, Barnhart BC, Murmann AE, Burkhardt JK and Peter ME: Molecular ordering of the initial signaling events of CD95. Mol Cell Biol 22: 207-220, 2002.

14. Lautrette C, Loum-Ribot E, Petit D, Vermot-Desroches C, Wijdenes $\mathbf{J}$ and Jauberteau MO: Increase of Fas-induced apoptosis by inhibition of extracellular phosphorylation of Fas receptor in Jurkat cell line. Apoptosis 11: 1195-1204, 2006.

15. Desbarats J, Birge RB, Mimouni-Rongy M, Weinstein DE, Palerme JS and Newell MK: Fas engagement induces neurite growth through ERK activation and p35 upregulation. Nat Cell Biol 2: 118-125, 2003.

16. Shinohara H, Yagita H, Ikawa Y and Oyaizu N: Fas drives cell cycle progression in glioma cells via extracellular signalregulated kinase activation. Cancer Res 60: 1766-1772, 2000.

17. Hug H: Fas-mediated apoptosis in tumor formation and defense. Biol Chem 378: 1405-1412, 1997.

18. Weller M, Frei K, Groscurth P, Krammer PH, Yonekawa Y and Fontana A: Anti-Fas/APO-1 antibody-mediated apoptosis of cultured human glioma cells. Induction and modulation of sensitivity by cytokines. J Clin Invest 94: 954-964, 1994.

19. Saas P, Walker PR, Hahne M, Quiquerez AL, Schnuriger V Perrin G, French L, van Meir EG, De Tribolet N, Tschopp J and Dietrich PY: Fas ligand expression by astrocytoma in vivo: maintaining immune privilege in the brain? J Clin Invest 99: 1173-1178, 1997

20. Comte I, Battu S, Mathonnet M, Bessette B, Lalloue F, Cardot P and Ayer-Le Lievre C: Neural stem cell separation from the embryonic avian olfactory epithelium by sedimentation fieldflow fractionation. J Chromatogr B 843: 175-182, 2006.

21. Bégaud-Grimaud G, Battu S, Liagre B, Leger DY, Beneytout JL and Cardot PJP: Pre-apoptotic sub-population cell sorting from diosgenin apoptosis induced 1547 cells by two sedimentation field-flow fractionation devices. J Chromatogr A 31: 883-892, 2007.

22. Lautrette C, Cardot PJP, Vermot-Desroche C, Wijdenes J, Jauberteau MO and Battu S: SdFFF purification of immature neural cells from a human tumor neuroblastoma cell line. J Chromatogr B 791: 149-160, 2003.

23. Yu SC, Ping YF, Yi L, Zhou ZH, Chen JH, Yao XH, Gao L, Wang JM and Bian XW: Isolation and characterization of cancer stem cells from a human glioblastoma cell line U87. Cancer Lett 265: 124-134, 2008.

24. Legembre P, Beneteau M, Daburon S, Moreau JF and Taupin JL: Cutting edge: SDS-stable Fas microaggregates: an early event of Fas activation occurring with agonistic anti-Fas antibody but not with Fas ligand. J Immunol 171: 5659-5662, 2003.

25. Moalic S, Liagre B, Corbiere C, Bianchi A, Dauca M, Bordji K and Beneytout JL: A plant steroid, diosgenin, induces apoptosis, cell cycle arrest and COX activity in osteosarcoma cells. FEBS Lett 506: 225-230, 2001.

26. Bégaud-Grimaud G, Battu S, Lazcoz P, Castresana JS, Jauberteau MO and Cardot PJP: Study of the phenotypic relationship in the IMR-32 human neuroblastoma cell line by sedimentation field flow fractionation. Int J Oncol 31: 883-892, 2007. 
27. Bertrand J, Liagre B, Bégaud-Grimaud G, Jauberteau MO, Cardot P, Beneytout JL and Battu S: Study of diosgenininduced apoptosis kinetics in K562 cells by sedimentation fieldflow fractionation. J Chromatogr B 869: 75-78, 2008.

28. Battu S, Cook-Moreau J and Cardot PJP: Sedimentation fieldflow fractionation: methodological basis and applications for cell sorting. J Liq Chromatogr Relat Technol 25: 2193-2210, 2002.

29. Chen J-h, Bian X-W, Yao X-H, Gong W, Hu J, Chen K, Iribarren P, Zhao W and Zhou X-D: Nordy, a synthetic lipoxygenase inhibitor, inhibits the expression of formylpeptide receptor and induces differentiation of malignant glioma cells. Biochem Biophys Res Commun 342: 1368-1374, 2006.

30. Kania G, Corbeil D, Fuchs J, Tarasov KV, Blyszczuk P, Huttner WB, Boheler KR and Wobus AM: Somatic stem cell marker prominin-1/CD133 is expressed in embryonic stem cellderived progenitors. Stem Cells 23: 791-804, 2005.

31. Williams PS, Lee S and Giddings JC: Characterization of hydrodynamic lift forces by field-flow fractionation. Inertial and near-wall lift forces. Chem Eng Commun 130: 143-166, 1994.

32. Leger DY, Battu S, Liagre B, Beneytout JL and Cardot PJP: Megakaryocyte cell sorting from diosgenin-differentiated human erythroleukemia cells by sedimentation field-flow fractionation. Anal Biochem 355: 19-28, 2006.

33. Bégaud-Grimaud G, Battu S, Liagre B, Léger DY, Beneytout JL and Cardot PJP: Pre-apoptotic sub-population cell sorting from diosgenin apoptosis induced 1547 cells by sedimentation fieldflow fractionation. The effect of channel thickness on sorting performance. J Chromatogr A 1128: 194-202, 2006.

34. Caldwell KD, Nguyen TT, Murray TM, Myers MN and Giddings JC: Observations on anomalous retention in steric field-flow fractionation. Sep Sci Technol 14: 935-946, 1979.

35. Chmelik J: Different elution modes and field programming in gravitational field-flow fractionation; I. A theoretical approach. J Chromatogr A 845: 285-291, 1999.

36. Giddings JC: Field-flow fractionation: analysis of macromolecular, colloidal, and particulate materials. Science 260: 1456-1465, 1993.

37. Martin M and Williams PS: Theoretical basis of field-flow fractionation. In: Theoretical Advancement in Chromatography and Related Separation Techniques. Dondi F and Guiochon G (eds). NATO ASI Ser., Ser. C: Mathematical and Physical Sciences, Kluwer, Dordrecht, pp513-580, 1992.
38. Schure MR, Caldwell KD and Giddings JC: Theory of sedimentation hyperlayer field-flow fractionation. Anal Chem 58: 1509-1516, 1986

39. Tong $X$ and Caldwell KD: Separation and characterization of red blood cells with different membrane deformability using steric field-flow fractionation. J Chromatogr B 674: 39-47, 1995.

40. Chmelik J: Applications of field-flow fractionation in proteomics: presence and future. Proteomics 7: 2719-2728, 2007.

41. Leger DY, Battu S, Liagre B, Cardot PJP and Beneytout JL: Sedimentation field flow fractionation to study human erythroleukemia cell megakaryocytic differentiation after short period diosgenin induction. J Chromatogr A 1157: 309-320, 2007.

42. Corbière C, Battu S, Liagre B, Cardot PJP and Beneytout JL: SdFFF monitoring of cellular apoptosis induction by diosgenin and different inducers in the human 1547 osteosarcoma cell line. J Chromatogr B 808: 255-262, 2004.

43. Leger DY, Liagre B, Cardot PJP, Beneytout JL and Battu S: Diosgenin dose-dependent apoptosis and differentiation induction in HEL cell line and SdFFF monitoring. Anal Biochem 335: 267-278, 2004.

44. Caldwell KD, Cheng ZQ, Hradecky P and Giddings JC: Separation of human and animal cells by steric field-flow fractionation. Cell Biophys 6: 233-251, 1984 .

45. Reschiglian P, Zattoni A, Roda B, Michelini E and Roda A: Field-flow fractionation and biotechnology. Trends Biotechnol 23: 475-483, 2005

46. Westerlund U, Moe M, Varghese M, Berg-Johnsen J, Ohlsson M, Langmoen IA and Svensson M: Stem cells from the adult human brain develop into functional neurons in culture. Exp Cell Res 289: 378-383, 2003.

47. Owens GC, Orr EA, Kleinschmidt De Masters BK, Muschel RJ, Michael EB and Kruse CA: Overexpression of a transmembrane isoform of neural cell adhesion molecule alters the invasiveness of rat CNS-1 glioma 1. Cancer Res 58: 2020-2028, 1998.

48. Noble M, Albrechtsen M, Moller C, Lyles J, Bock E, Goridis C, Watanabe $\mathrm{M}$ and Rutishauser U: Glial cells express N-CAM/D2CAM-likc polypcptides in vitro. Nature 316: 725-730, 1985. 